\title{
Assessment of Impact of Fuel Subsidy Removal on Socio-economic Characteristics: A Survey of Households in Maiduguri, Borno State, Nigeria
}

\author{
Abdulkadir Baba Mohammed*, Funmilola Fausat Ahmed, Abdulkabir Niran Adedeji \\ Department of Economics, Faculty of Social Sciences, University of Maiduguri, Maiduguri, Nigeria \\ Email address: \\ babaabdulkadirmoh@gmail.com (A. B. Mohammed), funmilolafausat123@gmail.com(F. F. Ahmed), \\ drabdulkabir@unimaid.edu.ng (A. N. Adedeji) \\ ${ }^{*}$ Corresponding author
}

\section{To cite this article:}

Abdulkadir Baba Mohammed, Funmilola Fausat Ahmed, Abdulkabir Niran Adedeji. Assessment of Impact of Fuel Subsidy Removal on Socio-economic Characteristics: A Survey of Households in Maiduguri, Borno State, Nigeria. Journal of Business and Economic Development. Special Issue: Towards Entrepreneurial Development for Employment Generation, Poverty Reduction and Conflict Resolution. Vol. 5, No. 1, 2020, pp. 10-20. doi: 10.11648/j.jbed.20200501.12

Received: December 27, 2019; Accepted: December 27, 2019; Published: February 11, 2020

\begin{abstract}
Subsidy has been one of the means of trickling economic effect down to reach majority adopted by many countries, including Nigeria. Recently, in Nigeria, subsidy on petroleum was removed which has led to a great macro-based debates. However, a study on such effect on individual might better provide important information on the impact of the policy, especially the impact on wellbeing of the poor. Thus, this study assessed the impact of fuel subsidy removal on the socioeconomic characteristics of households in Maiduguri metropolis, Borno state, Nigeria. Survey data were collected and analysed using descriptive statistics and simple regression method. Result on socioeconomic characteristics revealed that about $70.4 \%$ of respondents in the study area were male, about $61.3 \%$ were married, $41.5 \%$ fall within the ages of $30-39$ years. Besides, $50.7 \%$ had tertiary education, $52.1 \%$ were civil servants and about $34.5 \%$ have income level ranges between $\$ 40,000$ - $\$ 59,999$ monthly. It was also revealed that $56.3 \%$ of the respondents had $8-10$ family members, while $57.7 \%$ of them have $1-5$ dependents. On the other, the inferential statistic result revealed that the households' characteristics variable were positively related to fuel subsidy removal, significant at $1 \%$, except households' age. For sustainability, attention should be focused on workers' wages and salaries increase, family planning and transportation costs reduction as these may alleviate hardship of fuel subsidy removal on low-income earners in Nigeria.
\end{abstract}

Keywords: Fuel Subsidy Removal, Socioeconomic Development, Wellbeing, Sustainability

\section{Introduction}

Subsidy has been one of the means of tricking economic effect down to reach majority adopted by many governments. It often comes in form of rebate on price of commodity consumption voucher, tax reduction and even cash. Generally, subsidy is an economic policy usually embarked to make essential goods and services affordable for lowincome earners to improve their standard of living and for promoting businesses. The effectiveness of such policy would reflect on economic activities in the country.

In Nigeria, for instance, fuel subsidy was introduced in 1973 [12] to make petroleum products cheaply available and affordable to general populace, and also to make majority directly benefit much from the endowed resources of the country. Oil price in the international market has been fluctuating. The price of the product is characterized to be indeterminate and inherently volatile. It was around $\$ 50$ per barrel in 2016, soared to $\$ 64.46$ in 2019 , compared with the price $\$ 120$ in 2014 which also affects the pump price. One more important aim of fuel subsidy is to stabilize the fuel price in the wake of increased price. However, the benefits of fuel subsidy in Nigeria was short lived as the government removed the subvention in 2016. The government claimed that the subsidized payments made on refined petroleum imported to the country is huge, and that subsidized fuel are 
not sold in the country but either a fictitious or re-exported to neighbouring countries, and that payments made to subsidize fuel has not benefited the citizens but illegal cartel. The authority claimed also that the policy has led to several smuggling of petroleum product out of the country, fuel diversion, hoarding and over invoicing by petroleum marketers; and that fuel subsidy reduced the revenue that could had used for infrastructure, agriculture and fixing the decayed refineries. To populace, if fuel subsidy is removed, they stand to benefit nothing from the endowed oil-resource of the country as the effect would adversely affect their livelihoods over spilling on cost of production which in turn would increase the prices of goods and services [29].

The policy of fuel subsidy removal has been on-going for some years in Nigeria. Fuel subsidy had once removed in 1980 and 2000 during which the cost of fuel increased and as well the prices of commodities rose almost by $50 \%$. In many cases when subsidy is removed and/or oil pump price increased, many individuals particularly the low income populace often is at receiving end as this would reflect to fall in living standard of this group. The last fuel subsidy removal in 2016 prompted the government to introduce Social Intervention Programme (SIP) with the view fetch the issues that usually arise from fuel subsidy removal. The SIP is basically designed to mitigate the effects of fuel subsidy removal and accelerate economic growth through investments in critically needed infrastructures as well as social services such as education, health care services, job creation, and vocational training. In spite this initiative, the living condition of people appears not improve as prices of goods and services are considerably high which possibly as a result of removal of fuel subsidy. Nigeria is not alone in this trend, in Cameroon for example, in 2014, fuel prices increased after fuel subsidy was removed, rose by $14 \%$, but later replace after the transport workers threatened to go on strike. The same was the case in Guinea, Ghana and Chad who share similar experiences as a result of removal of fuel subsidy by their respective governments. This create a rise in automobile fuel, consequently cost of transportation increases and even overhead costs of small medium scale enterprises (SMEs) increased as many operators relied on generators powered by fuel. This culminated to the negative consequences in the living condition of people in these countries.

The low economic condition of people as a result of fuel subsidy removal appears to more is pronounced in Northern region of Nigeria where standard of living is grinding. The region has the highest poverty prevalence, about $76.8 \%$, and the northeast, Borno precisely, has the highest level of poverty (NBS, 2015). However, quality-of-life assurance practitioners and stakeholders are yet to pay concentrative attention and consider the effect the fuel subsidy removal may likely add to abject wellbeing in this state. This is a serious concern that needs to be explored. The issue of fuel subsidy removal has led to a great debate on which the assessments of SIP and previous studies [25, 33, 14] on its effect on living condition and wellbeing in Nigeria are macro-based aggregation which may not actually capture the individual effect. The discussion over its impact on the masses and desirability in Nigeria remains unresolved. Besides, does fuel subsidy removal harm wellbeing of the poor in resource countries, like Nigeria? If so, are there better alternative measures for reducing its negative effects on the poor? These questions needed to be addressed.

Taking Borno for a case in this scenario may give better information about such effect. Borno is classified to have low economic status in the country as mentioned above, it shares border with other three less-economic privileged countries: Chad, Cameroon and Niger; where foreign migrants come in search for employment and better life. As such removal of subsidy may increase the costs of basic living standards, a key factor that might have be the cause of high poverty rate in the state. Hence, this study intends to shed comprehensive light on the impact of fuel subsidy removal on living standard of households in Borno state, using Maiduguri for analysis.

\section{Literature Review}

\subsection{Subsidy and Fuel Subsidy}

A subsidy is an economic benefit or financial aid provided by a government to support a desirable activity, so as to keep prices low, maintain the income of the producers of critical or strategic products, maintain employment levels, or induce investment to reduce unemployment. It can tentatively be defined as any government program that potentially permits the firm to increase its profits beyond what they would have been in the absence of the government program [10]. A subsidy can also be referred to as an assistant to a business or economic sector or producers. The major aim of all subsidies is to reduce the market price of an item below its cost of production. Most subsidies are put in place by the government for producers or are distributed as subventions in an industry to prevent the decline of that industry or simply to encourage it to hire more labour (as in the case of a wage subsidy). Examples are subsidies to encourage the sale of exports, subsidies on some foods to keep down the cost of living, especially in urban areas, and subsidies to encourage the expansion of farm production and achieve self-reliance in food production [4].

A subsidy is a reverse tax. It is a deliberate attempt by government to support a chosen economic agent, a consumer and a provider and it can be applied in any market that involves the buying and selling of products or services. It is basically a government action that decreases the consumption price of the consumer and or increases the selling price of the producer. subsidies is also defined as any government action that lowers the cost of energy production, raises the revenues of energy producers or lowers the price paid by energy consumer (Citizens Guide to Energy Subsidies in Nigeria, 2011). A subsidy is an assistance paid to a business or economic sector mainly by the government to prevent the decline of that industry [35]. Subsidy is meant to contribute to economic growth, poverty reduction and security of 
supply.

Fuel subsidy means that a fraction of the price that consumers are supposed to pay for the use of petroleum products is paid by the government so as to reduce the price burden. Fuel subsidy is a government programme created to reduce how much people have to pay for petroleum products, which include: Premium Motor Spirit (Petrol), Automotive Gas Oil (Diesel) and Dual Purpose Kerosene (Kerosene), and to protect the citizens from crude oil volatility in the international market. Fuel subsidy is particularly popular in oil producing countries, such as: Venezuela, Iran, Saudi Arabia, Egypt, Burma, Malaysia, Kuwait, China, Taiwan, South Korea, Trinidad and Tobago, and Brunei and some non-oil producing countries producing countries, such as chad, Cameroon, Niger, etc. [9].

Fuel subsidy is a taxpayer funded payment made to encourage development/distribution of alternative fuels as well as for the exploration and development of more traditional energy sources. A fuel subsidy is also any government action that lowers the cost of fossil fuel energy production, raises the price received by energy producers or lowers the price paid by energy consumers. However, the application of or the use of subsidies is not exclusive to developing economies. Subsidies span different types of economic activities, the most featured in popular press tend to be agricultural and energy related subsidies. The subsidy could be direct in the form of price controls, tax exemptions or the provision of grants, this is more or less entails the injection of cash back into the hands of either the consumer or the producer. The indirect form of subsidy is more in the form of the provision of industrial input requirements in the form of favorable regulator, frameworks, research and development. Different types of subsidies include the following: grants and other direct payments, tax concessions, cross subsidies, credit subsidies, government guarantees and hybrid subsidies [30].

Within the Nigerian context, fuel subsidy means to sell petrol below the cost of importation. It is a mechanism designed by the government to keep the price consumers pay for products below market levels to specifically make targeted goods and services affordable to consumers who ordinarily may not be able to afford them. Subsidies could benefit people and businesses in the form of tax deductions, grants, exemptions or price control. In Nigeria, fuel subsidy as designed in the Petroleum Product Pricing Regulatory Agency (PPPRA, 2012) template is the compensation due to importers of petroleum products based on the difference between landing cost less ex-depot price of fuel. This is to ensure that consumers pay a regulated amount of petroleum products at the same time, ensuring that producers get their real costs remunerated. It is a scheme meant to alleviate poverty by providing energy security for the country. Subsidies affect prices or costs indirectly, such as regulations that tilt the market in favour of a specific fuel, government funded technology or research and development [1].

Fuel subsidy removal programs are design to achieve stability in the level of economic development of a country.
There is evidence that successful countries take gradual approach, engaged in conscientious research prior to implementation and followed by a rigorous approach to policy making, that effective communications and a fair level of trust between citizens and government may be the other critical success factors in such an exercise [10].

\subsection{The Impact of Fuel Subsidy on Livelihood}

The Nigerian economy over the years has been programmed to revolve around the supply of cheap petroleum products. An average household in Nigeria depends on subsidised by-product of crude oil such as petrol and kerosene for domestic and commercial use. This dependence is not helped either as public electricity supply from Power Holding Company of Nigeria (PHCN) is epileptic. Almost every home and business is powered by generators with subsidised petrol. The few small scale business such as hotels, barbers, welders, hair dressers, paper sellers, food venders, private and government hospitals etc. all relied on subsidised fuel. Transportation cost for instance has gone up and this results in spiral effect on other sectors especially as all other businesses revolve around transportation sectors. It is obvious that fuel subsidy removals have worsened the country's already inflation rate. In fact, they have resulted in hyper- inflation as prices of goods and services have skyrocketed beyond reaches of many [18]. Accordingly this has affected welfare of household through inflation which in turn lead to diversion of resources from savings and investment to meet the day-today needs [33].

It is on record that fuel subsidy has been consistently removed from 1986 during the president Babangida's administration, yet Nigerians have no cause to smile. The price of fuel continued to rise until the emergence of Yar'adua's administration, when the price stabilised at $\$ 65$ a litre. In view of the forgoing, it is not out of place to state without mincing words that during these periods of subsidy removal, Nigerians never experienced good times or moment of joy, instead the demand eluded them, in other words the benefit expected from the removal of fuel subsidy was vividly lost. This was followed by rise in poverty level among Nigerian masses due to increased unemployment rate, uncontrolled inflation, lack of health facilities and other social vices that is to say therefore, withdrawal of fuel subsidy translated in to automatic increase in the pump price per litre of the commodity [7].

Experience has shown that changes in energy prices will indirectly affect the cost of public transport, manufacturing, distribution of goods, and other sectors of the economy. Particularly, the low income households, even small amount of energy can be crucial for income generating activities (including agriculture) and for ensuring access to services and markets. This means that livelihoods of the poor are likely to be more affected by energy prices than the high income groups. For high income households, energy consumption is more likely to be compressible, that is, relatively more energy (such as transport fuels) is used for 
non-essential purpose [8].

Adopting the sustainable livelihoods approach provides a way to improve the identification, appraisal and, implementation and evaluation of development programmes so that they better address the priorities of poor people, both directly and at a policy level [19]. What contribution can subsidy removal approach make to address the priorities of poor people at the policy level? Some argue that government regulations have high impact on the masses [24] affirm that sustainable livelihoods have much to contribute at the level of policy. The sustainable livelihood approach recognises the importance of polices and institutions in governing people's access to livelihood assets, and in influencing their livelihood strategies and their vulnerability to shocks and stresses. Hence, the approach advocates a more upstream approach to reducing poverty.

An important contributions of government regulation to livelihood is to direct the policy analysis to focus on livelihood of poor. An analysis of policy for sustainable livelihood requires an understanding of the livelihood priorities of the poor, the policy sector that are relevant to them, and whether or not appropriate policies exits in those sectors. The policy priorities of poor people will be realising more effectively if they have the capacity to articulate their demands and influence the policy process [32].

Sustainable livelihood approach also takes a cross sectorial perspective. Whereas policy is often made in relation to single sector, such as oil, a sustainable livelihood approach looks at how policy affects people's livelihoods. Oil policy from this perspective is not just a matter of improving oil production. It must be examined from the perspective of its linkages with other areas, such as education, health and finance. At a practical level, this may mean the need to make trade-offs between different aims [17].

There are economic arguments for removing fuel subsidies, some said fuel subsidies are not efficient as they result in redistribution in the economy, and also inequitable as the rich people received more of the benefits than poor. Studies [15] have shown that fuel subsidies are ineffective in fuelling economic growth or ensuring equitable distribution of income. In fact, most of studies suggested that fuel subsidy hamper economic growth and undermined the principle of equity [25]. This is consistent with [14] who point that subsidy reform more affects real household income.

Another argument of the effect of subsidy removal centred on household consumption. The argument is that subsidy removal limits the propensity of the poor to afford basic needs, reduces accessibility of the poor to essential daily services, and poses a threat to their livelihood. [14] insisted that subsidy placement is indirect form of wealth redistribution to the poor and if it is taken away, the government must alternatively compensate the poor, utilise the saving and explain how inevitable inflation will be managed.

A survey by the National Bureau of Statistics [21] provides a detailed breakdown of households' expenditure on food, education, health and other goods. It is affirmed that subsidy removal have direct effects on these variable as indicated by the findings, the impact of fuel subsidy removal is great on food, education and health. Subsidies are justified as a mechanism for redistributing natural resources revenue and for supporting poor households. It is critical to understand the state of repressiveness. Various studies have highlighted how subsidies failed to reach the poor households. [7] analysed a sample of 20 developing countries from around the world and find that on average the richest $20 \%$ benefits six times more from fuel subsidies than the poorest $20 \%$ (in absolute terms).

However, proponents of policy have enumerated the numerous benefits of the subsidy removal policy. [35] opine that full implementation of the policy would have enormous benefit to economy as the removal will raise fuel snuffing across Nigerian borders thereby eliminating scarcity in Nigeria. As expert claimed to have said that "if we borrow to subsidise today, it is our children that are subsidising us". For Nigeria, [30] asserted that fuel subsidy removal would annually release about $\$ 1$ trillion for investment and as such this would create employment and alleviate poverty. $\mathrm{He}$ explained the economy is paying the cost of deregulated fuel without getting the benefits of deregulation. He further argued that fuel subsidy is a consumption subsidy that is wasteful, impedes investment and promotes corruption. The subsidy prevents the creation of a domestic refining and petrochemical sector through private investment. He also added that the inflationary effect of oil subsidy removal is one-off economic adjustment, which vastly outweighed by the benefits. [30] is sure that many Nigerians were now ready to accept higher oil prices in return for elimination of cycles of instability and security. The sole factors preventing investment in domestic refineries is the oil subsidy. Full industry deregulation will produce a huge domestic private sector, refining and petrochemical sector. This will increase the value of our exports and create jobs locally rather than subsidy.

\subsection{Empirical Review}

[34] Conducted a study on the impact of fuel subsidy removal on socio economic development of Nigeria (19802012) using a price pass-through model. The study employed econometric approach, the error correction model to examine both the short and long run impact of fuel subsidy removal on socio-economic development in Nigeria. Variables used in the study were GDP/cap represents GDP per capita (proxy for socio-economic development) PPP represents the Pump Price of petrol, (domestic price of fuel), and GD P/c a p $t-1$ (lagged value of the dependent variable). The study discovered that the fuel subsidy removal does not have short run impact on the social well-being of Nigerians. However, the long run impacts of this policy revealed that the deregulation of the downstream sector will ultimately lead to future economic development of the country.

Also, [25] conducted a study on fuel subsidy removal and Nigerian economy. The study examined how fuel subsidy removal affects some key sectors of the economy as well as 
its effects on economic development of the country. These sectors include health, transportation, education and power sector. Descriptive statistic was used to analyse the impact of fuel subsidy removal on the development of those sectors. Findings of the research work revealed a high level of impact in health (37.7\%), transportation (82\%), education (33\%) and power sector $(56 \%)$, a low impact was felt in agriculture (21\%), infrastructure and basic amenities (16.4\%). If these sectors of the economy are in a very good shape, it will not only go a long way in sustaining and reviving other sectors of the economy, it will also help to hasten growth and development in Nigeria.

[28] Conducted a study on subsidy removal and investment challenge in Nigeria's petroleum industry. The study examined the various regimes of petroleum products price increases, subsidy payments and its effectiveness in stimulating investments in the industry in Nigeria. Secondary data were collected from the Nigerian National Petroleum Corporation (NNPC), Central Bank of Nigeria (CBN), Petroleum Products Pricing and Regulatory Agency (PPPRA), and government records. Deregulation would have immediate negative effects on real household incomes. Negative reactions can be mitigated with adequate palliative measures and effective education and public enlightenment. In the short run, the prices of petroleum products would go up significantly but would drop when the products of the new refineries are released into the market. This study went beyond subsidy removal. It conducted empirical study on its effectiveness or otherwise on investment generation to proffer alternative. It revealed that subsidy removal did not stimulate investment. Alternative course of action was recommended. The studies indicate that there exist benefits to be derived from subsidy removal which only come in the long run. Therefore, adequate measures should be put in place to alleviate short term disruption in the form of palliative measures to cushioned the hardship subsidy removal might cause. The result is also consistent with theoretical and some empirical findings that removal of fuel subsidy results in efficiency leading to economic growth.

In a study conducted [8] on economic implication of fuel subsidy removal in Nigeria. The arguments for and against fuel subsidy removal in Nigeria as an economic discourse using descriptive statistics (Bar chart) was raised. The study notes the growing antagonism from people towards the removal of fuel subsidy. It was discovered that the sector was characterized by gross corruption, defective record-keeping, insufficient supply, smuggling and inefficiency. It also examines various regimes of fuel price increases, subsidy payments and its effectiveness or otherwise in stimulating economic activities in Nigeria and make recommendations on the need to build more refineries in order to make the product more available to the people at an affordable pump price. Also, the study recommends that for the smooth operation of the petroleum sub sector, government should always engage the people in policies that will affect them.

[26] conducted a study on the impact of fuel price increase on the Nigerian economy (whether negative or positive). The study adopted a survey research design approach to evaluate the level of effect the fuel price increase has on the Nigerian economy. The population of the study is made up of civil servants, market men and women and staff in the private sectors concerned with petrol and gas affairs. A sample size of 120 persons was selected at random. A pre- test was conducted and outcome yield " $r$ " $=0.92$ indicating a high degree of consistency and reliability. The pearson product moment correlation coefficient was used to confirm the formulated hypotheses. Finding revealed that there is a significant relationship between the recent increases in fuel prices and economic growth in Nigeria. It was also discovered that the Nigeria economy is not developing because of the effect of fuel price hike on purchasing power and finally the finding showed that there is significant relationship between increase in pump price of petroleum and food security. The study therefore, recommended that government should retain fuel subsidy, while expediting the construction of the three proposed refineries, and fuel subsidy should be removed as soon as these new refineries are commissioned.

[2] Conducted a study on enlightenment to the impact of fuel subsidy removal in Nigeria employing a linear function approach to analyse the effect of fuel subsidy removal on the value of Nigerian Naira and local production in the country. Data for about eight different periods where fuel hike occurred in Nigeria was used, and a mathematical model with the aid of a graph, was also developed to aid estimated calculation of naira's value. The study discovered that increase in fuel pump price has an adverse effect on the standard of living of the people, since fuel is essential for the transportation of major Nigerian commodities, such as agricultural produce and other market product. The significant impact of the upsurge of petroleum pump price on the price of goods transport initiates this study; with the aim of checking its effect on the purchase value of naira. The study however, recommended the implementing of policies that encourage industrialization and provide a market environment which will encourage technological competitiveness that can drive economic growth.

\section{Method}

This study obtained primary and secondary data for analysis. The primary data were collected through interview and questionnaire administered to the households heads in Maiduguri Metropolis Council, state capital of Borno. This area was chosen for the poverty rate rank in the state and the density of the Metropolis is high. Questionnaire was selfadministered with the help of some community members in the study area. However, out of the 384 questionnaire administered, 14 were inappropriately completed. As a result, only 370 questionnaire were used for analysis. The total number of households' heads in Maiduguri metropolis, 113,265, is obtained from National Population Commission 2018 (NPC). This study adopts simple random sampling technique was employed for selecting of eight wards out of 
29 wards in Maiduguri and 48 households were selected from each of these wards, given 384 respondents in total. While secondary data were collected from $\mathrm{N}$-power office Maiduguri.

Descriptive statistics and simple regression methods were employed to analyze the data. The dependent variables age, educational level, family size is used as a proxy for livelihood regressed on household's income, a proxy for fuel subsidy removal. The study assumed that households' income is proportionally measured the fuel subsidy as this determined the level of purchasing power which determined the livelihood.

\section{Descriptive and Regression Results}

\subsection{Descriptive Result}

The socio-economic characteristics of the respondents were analysed using descriptive statistics. The results were presented in Table 1 below and discussed according to the research objectives.

In Table 4, gender distribution of the household heads showed that $69.7 \%$ were male and $30.3 \%$ were female. The classification of marital status from the distribution of the respondents revealed that $61.3 \%$ were married, $32.4 \%$ were divorced, and $6.3 \%$ were widows. It can be seen that most of the respondents were married. The marital status of a person is expected to determine the extent of responsibility of that person and the manner in which he or she will allocate scarce resources at his or her disposal. This implies that majority of the respondents' may require high quantity of fuel and hence the effect of subsidy removal on the products demanded for livelihood sustenance. This finding confirms the study by [20]. The marital status indicates the weight of responsibility, the extent of commitment to his or her job as well as the quantity of fuel he or she is likely to use at a point in time. Single households' holders are more likely to demand less of the fuel energy due to the small size of their dwelling compared to those who are married with many dependents to take care of.

The age range of the respondents between $30-39$ and 2029 scored $41.1 \%$ and $27.5 \%$ respectively. Only about $5.6 \%$ were 50 years and above. This implies that about total of $74.2 \%$ of the respondents are in active age and engage in various activities that involve the use of fuel in the study areas.

The distribution of the respondents according to educational background showed that $49.1 \%$ and $22.9 \%$ had tertiary and secondary qualifications respectively, while only $9.2 \%$ had informal education. Implicatively, most of them are literate with majority having tertiary educational qualification. Respondents that possess high educational qualifications are more likely to feel less impact of subsidy removal owing to higher income earned as well as high propensity in optimum utilisation of resources at their disposal. This outcome is confirmed in the study [16]. Who observed that higher education level of individual's results in lower energy consumption, increases efficiency and thereby raises his living standard.

Table 1. Socioeconomic Characteristics of Respondents $n=370$.

\begin{tabular}{|c|c|c|c|}
\hline Variables & & Frequency & Percentage \\
\hline \multirow[t]{2}{*}{ Gender } & Male & 258 & 69.7 \\
\hline & Female & 112 & 30.3 \\
\hline \multirow[t]{3}{*}{ Marital Status } & Married & 228 & 61.3 \\
\hline & Divorced & 122 & 32.4 \\
\hline & Widow & 20 & 6.3 \\
\hline \multirow[t]{4}{*}{ Age } & 20-29 years & 102 & 27.5 \\
\hline & $30-39$ years & 152 & 41.1 \\
\hline & 40-49 years & 96 & 25.9 \\
\hline & 50 years and above & 20 & 5.6 \\
\hline Educational & Informal & 34 & 9.2 \\
\hline \multirow[t]{3}{*}{ Qualification } & primary & 69 & 18.8 \\
\hline & Secondary & 85 & 22.9 \\
\hline & Tertiary & 182 & 49.1 \\
\hline \multirow[t]{4}{*}{ Occupation } & civil servant & 193 & 52.0 \\
\hline & Farmers & 100 & 27.0 \\
\hline & business & 71 & 19.0 \\
\hline & Artisan & 6 & 2.0 \\
\hline Level & $<\Vdash 20,000$ & 20 & 5 \\
\hline \multirow[t]{5}{*}{ of Income } & $\aleph 20,000-\backsim 39,999$ & 34 & 9.2 \\
\hline & $¥ 40,000-\aleph 59,999$ & 125 & 34.5 \\
\hline & 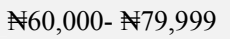 & 73 & 19.7 \\
\hline & $\$ 80,000-\aleph 99,999$ & 29 & 7.7 \\
\hline & $>£ 100,000$ & 89 & 23.9 \\
\hline \multirow[t]{4}{*}{ Family Size } & $2-4$ & 80 & 21.6 \\
\hline & $5-7$ & 208 & 56.3 \\
\hline & $8-10$ & 50 & 13.6 \\
\hline & 11 and above & 32 & 8.5 \\
\hline \multirow[t]{3}{*}{ Dependents } & $1-5$ & 210 & 56.7 \\
\hline & $6-10$ & 95 & 26.3 \\
\hline & 11 and above & 65 & 16.9 \\
\hline
\end{tabular}

The frequency distribution of the respondents by occupation revealed that about $52 \%$ were civil servants, and about $27 \%$ were farmers. This implies that the civil servants, with a fixed income level, stand higher chances of being affected by subsidy removal than the rest of the respondents due to their inability to increase income monthly. As for the farmers and business men/women, they could shift the increase in price of inputs emanating from subsidy removal on to the consumers so as to offset the differences thereby maintaining a desired income level.

Income distribution of the respondents from Table 1 revealed that about $23.9 \%$ of the respondents' earn more than $\$ 100,000$, while only about $4.6 \%$ earn below $\$ 20,000$ per month. According to economic theory, the level of consumption of an individual depends largely on his level of current income as propounded by Keynes, the absolute income hypothesis; it states that, "the current real income is the most important determinant of consumption in the short run". In other words, the higher the individual's level of income, the higher will be his consumption level. Keynes used the parameter marginal propensity to consume in explaining this. Thus, respondents who fall within the income level between $\$ 80,000$ to $\$ 99,999$ and $\$ 100,000$ above $(31.6 \%)$ will be less affected compared to those in other groups. This implies that $68.4 \%$ of the respondents (with monthly income of less than 20,000 - 799,999 ) were the 
most affected owing to high cost of goods and services brought about by subsidy removal.

The distribution of the respondents by family size showed that $56.3 \%$ have 5 to 7 family members, while $8.5 \%$ have more than 11 members in the family. Increasing family size could exert more pressure on households needs such as food and fuel since these needs tend to increase with the number of persons in the households and depends also on the composition of households' size. This implies that as households size increases, the probability of negative impact of fuel subsidy removal on households also increases.

The distribution of the respondents with respect to number of dependents indicated that $56.7 \%$ had 1 to 5 dependents, while $16.9 \%$ had more than 11 dependents in the family.
Number of dependents is an important variable in the determination of a socioeconomic status of a households dwelling, as high child dependency ratio results in increased households' food requirements, heavy dependence on available households' income, as well as durables goods used at homes such as television, radio, etc. [6] opined that dependency ratio is often used as an indicator of economic burden in countries/households with high dependent are usually associated with high burden and vice versa. This is plausible as high child dependency ratio results in increased households' food requirements, probable reduction in quantity and quality of food, heavy dependence on available households' income, hence high probability of food insecurity.

Table 2. Impact of Fuel Subsidy Removal on Household's Livelihood.

\begin{tabular}{lllll}
\hline Statement & SA & A & N & DA \\
\hline Decrease in income level & $138(39.4 \%)$ & $145(39.4 \%)$ & $50(13.4 \%)$ & $17(5.6 \%)$ \\
Decrease in savings & $89(24.6 \%)$ & $171(46.5 \%)$ & $34(8.5 \%)$ & $45(12.0 \%)$ \\
Decrease in assets & $86(23.2 \%)$ & $138(66.9 \%)$ & $6(1.4 \%)$ & $21(5.6 \%)$ \\
Decline in occupational & $164(44.4 \%)$ & $160(43.0 \%)$ & $21(5.6 \%)$ & $31(8.5 \%)$ \\
Prospect Decline in knowledge/skill & $133(35.9 \%)$ & $209(55.6 \%)$ & $10(2.5 \%)$ & $10(2.8 \%)$ \\
\hline
\end{tabular}

Table 2 shows the impact of fuel subsidy removal on household's livelihood in the study area. The result revealed that $39.4 \%$ of the respondents agreed that fuel subsidy removal led to decrease in income, while only $5.6 \%$ disagree. Thus, the implication is that the introduction of the policy has seriously affected income level of people in the study area. Price level generally increased leading to inflation, which invariably affects disposable income. Income is money that an individual or business receives for providing goods or services or through investing capital. Income is used to fund day-to-day expenditures by people. Majority of the respondents in the study area receive their income from salary or wages earned from job. Subsidy removal has direct effect on income by reducing their purchasing power and consequently decreased tendency to consume. This assertion is affirmed by Milton Friedman's economic theory, the permanent income hypothesis, which states that people will spend money at a level consistent with their long term average income. The level of expected long term income then becomes thought of as the level of permanent income that can be spent. For example, if a worker is aware they will likely receive an income bonus at the end of particular pay period, it is plausible that their spending in advance of that bonus may change in anticipation of the additional earnings and vice versa. This implies that a fall in one's income would bring about reduction in consumption expenditure of an individual.

Also, the study revealed that fuel subsidy removal affected the volume of savings of respondents. About $46.5 \%$ of the respondents affirmed that their savings decreased as fuel subsidy was removed. This indicates that subsidy removal has been an additional liability to respondents in terms of reduction in the level of their savings. This could be as a result of shock that emanated from subsidy removal that has direct connection with income and savings. Saving as one of the households' livelihood components has been negatively affected as most of the respondents have experienced reduction in their savings caused by a fall in the disposable income. This assertion is in line with life cycle hypothesis which seeks to examine the relationship between consumption and saving. It posits that individuals trying to maintain stable level of consumption over time save in their working years for retirement. Consequently, life time resources, rather than current income, are what determine the level of consumption and savings ratio by an individual. In the light of the above proposition, fuel subsidy removal has cost respondents some proportion of their saving that is supposed to serve as future means of sustenance has been directed to current use.

The respondents, $66.9 \%$, agree that they experienced a decrease in assets as respondents have liquidated assets to meet immediate family needs. Assets generally enable individuals to increase their net worth, but in some cases assets ownership can help families even when the effects on net worth is modest. Conceptually, a central role of assets is to cushion the decline in consumption that might otherwise arise with a sudden income loss. As a result, some households have to draw down their assets or use it as collateral to borrow and replace loss income, thus potentially subjecting them to danger of lack of financial security provided by the possession of such assets [11].

It is found that $43.0 \%$ of the respondents agreed that there was a decline in occupational prospects, while only $5.6 \%$ were undecided. The survey therefore, indicates that removing subsidy on fuel had triggered a decline in prospect of households' occupations due to increased cost. Many households experienced decline in their day to day activities ranging from reduction in hour of work per day, and reduction in income as a result of low customer turnover. The reduction in hour of work experience by some individuals 
coupled with linkage and spill over effects associated with some type of occupation has caused some people moved from one form of job to another that might not necessarily be suitable for their skills. Linkage and spill over effects are those connections that coexist among occupations, for example, people who repair machines and equipment for organisations and individuals may lose their occupations due to low customer's turnover when such organisations and individuals no longer use these machines or cut down production owing to high cost of fuel.

On the decline in knowledge/skills, $43.0 \%$ of the respondents agree that this occurred as a result of fuel subsidy removal, while only $2.5 \%$ disagree. The result explains that the policy has cost them much in terms of application of skills in the production of goods and services in line with modern trend of production. The fact that some people depend on their skills as means of livelihood, others consider their skills as supplementary source of income generation. Fuel subsidy removal, might have affected the respondents in such a way that a reduction in disposable income, part of which is used in improving skills/knowledge in their various endeavours. For instance, the civil servant may be unable to improve his knowledge owing to short fall in disposable income. This is because he has to meet up with his primary needs before attending to other needs. Farmer may also experience similar challenges of funding in acquiring additional skill for improving crops yield in the course of carrying out his farming activities. Likewise the businessman/woman might also be affected in trying to improve business skills. Subsidy removed on fuel has led to diversion of resources and time supposedly meant for improving their capabilities and efficiency in their various endeavours.

Table 3 describes awareness of respondents on the strategies adopted by government in cushioning the effect of fuel subsidy removal. The respondents agreed that the conditional cash transfer is a means of alleviating hardship associated with subsidy removal as the programme was designed to provide funds for people in trading, youths, and farming activities to enable them withstand the difficulties associated with inadequate capital. [5] Affirmed that the policy was effective as it covers all the nuts and crannies of the entire nation targeting the most vulnerable in the society and has yielded positive impact on the beneficiaries.

Table 3. Perceptions on fuel subsidy removal and household's livelihood.

\begin{tabular}{|c|c|c|c|c|c|}
\hline Statement & $\mathbf{S A}$ & $\mathbf{A}$ & $\mathbf{N}$ & DA & SDA \\
\hline Conditional cash transfer scheme & $56(39.4 \%)$ & $53(37.3 \%)$ & $19(13.4 \%)$ & $8(5.6 \%)$ & $6(4.2 \%)$ \\
\hline Introduction of vocational centres & $36(25.4 \%)$ & $77(54.2 \%)$ & $18(12.7 \%)$ & $7(4.9 \%)$ & $4(2.8 \%)$ \\
\hline Introduction of $\mathrm{N}$-power & $51(35.9 \%)$ & $37(55.6 \%)$ & $42(2.5 \%)$ & $9(6.3 \%)$ & $3(2.1 \%)$ \\
\hline Enterprises \& empowerment program & $79(55.6 \%)$ & $39(27.5 \%)$ & $8(5.6 \%)$ & $8(5.6 \%)$ & $5(5.6 \%)$ \\
\hline Science technology and engineering & $64(45.1 \%)$ & $48(33.8 \%)$ & $14(9.9 \%)$ & $10(7.0 \%)$ & $6(4.2 \%)$ \\
\hline
\end{tabular}

Also, 37.3\% of the respondents are aware and agreed with the programme. This implies a high level of acceptance by the respondents, which is not unconnected with the fact that most of them are civil servants who are literate and are aware of most of the governmental policies and programmes especially those that are directly connected to their wellbeing. Not only that they have people under them as dependents as reflected by the questionnaire who might be among the beneficiaries of the scheme. These training centres provides opportunities for many unemployed people to be trained and empowered to become self-employed in the various skills such as, art and craft, brick making, welding among others.

The distribution of respondents with respect to the introduction of N-power as a palliative on the effects of fuel subsidy removal in the study area shows that $55.6 \%$ of the respondents agree, while $6.3 \%$ disagree. The $\mathrm{N}$-power scheme is the largest and the most popular among the palliatives because of the high number of direct beneficiaries involved and its multidimensional aspect, which include health, education and agriculture, thus, led to a high level of acceptance by the respondents. Under this scheme, a total of 200,000 graduates have so far been engaged across 36 states of the federation with the view of recruiting additional 300,000 to serve as volunteers' teachers, agricultural extension workers and health workers

Among the respondents, $27.5 \%$ agree that the government enterprises and empowerment programmes was a means of alleviating hardship accompanied by fuel subsidy removal. The scheme which focused on the provision of soft loan to people engaged in small scale businesses especially traders and artisans with insufficient capital for expansion have improved the lives of the beneficiaries tremendously. The outcome indicates that the introduction of the policy has yielded desired result as pointed out by [5] that the provision of soft loan for traders and artisans including agricultural workers has improved the lives of many across the country.

The result showed that $33.8 \%$ of the respondents agree with Science, Technology, Engineering and Mathematics (STEM) strategy by the government in militating against the effect of fuel subsidy removal. Most of the respondents have children in higher institutions and thus, explained the extent to which scholarship to students under this scheme have helped their wards in their studies by enabling them to have access to materials needed to equipped them academically. also, asserted that [5] science, technology, engineering and mathematics (STEM) contained in the social intervention programme of federal government has made a remarkable success in reducing hardship associated with having access to educational materials among students of tertiary institution as it provides scholarship to about 100,000 students studying science and technology across the country. 


\subsection{Regression Result}

The regression result in Table 4 showed the estimated results of the relationship between fuel subsidy removal, dependent variable represented by income, and household characteristics: house-head age, sex, educational level, family size, number of dependent and marital status. The $\mathrm{R}^{2}, 74 \%$, shows that the households' characteristics variables are important factors explain substantial variation of dependent variable. All are significantly positively related to households' income, except age. The coefficient of age was positive but insignificant indicating that the age of households is not likely to be affected by their income due to fuel subsidy removal. The impact with respect to age of younger and older households is less. This may be due to the fact that fuel as a source of energy is used by all household ages irrespective of age differences vis a vis income of respondents in the study area. The household head sex coefficient $(0.021)$, as well as education $(0.006)$, is found to be positive and significant at $5 \%$. This implies that sex and education predispose household heads. This reflects the level of awareness and enlightenment on measures taken to combat the effect of fuel subsidy removal. Family size, number of dependence as well as marital status (0.87), (0.39), (0.69) were all found to significant at $1 \%$ Also, respondents are more equipped economically to manage their households owing to formal knowledge gained by most of them. This finding is in conformity with a study conducted [16] observed in their studies that higher education level of individual's resulted in lower consumption of resources, increases efficiency and thereby raises his living standard.

Table 4. Regression output of Households 'livelihood.

\begin{tabular}{lllll}
\hline Dependent Variables & Coefficient & Std. Err & t-value & P-value \\
\hline House-head age & 0.824 & 0.926 & 0.889 & 0.248 \\
House-head sex & $0.021^{* *}$ & 0.004 & 5.250 & 0.007 \\
House-head Education & $0.006^{* *}$ & 0.001 & 4.367 & 0.023 \\
Family size & $0.870^{* * *}$ & 0.178 & 5.571 & 0.000 \\
Number of Dependent & $0.039^{* * *}$ & 0.007 & 6.176 & 0.019 \\
Marital status & $0.698^{* * *}$ & 0.113 & & 0.014 \\
constant & 0.096 & & & \\
$\mathrm{R}^{2}$ & 0.743 & & & \\
F-value & $35.693 * *$ & & & \\
\hline
\end{tabular}

Note: $* * * \& * *$ denote $1 \%$ and $5 \%$ significant levels respectively.

The coefficient of family size (0.870) is positive and significant at $1 \%$ indicating that all things been equal, the larger the household size, the more the influence of subsidy removal on its livelihood. The reason is that larger families spend more on food and other family needs than families with few numbers. Expenditure per head is higher in large families than in households with small family sizes. This finding is in line with a study conducted [27] who found that households with large family members mostly affected by subsidy removal.

The coefficient of number of household dependent (0.039) is positive and significant at $1 \%$ indicating that the households with many dependents are more likely to be affected by subsidy removal than households with few dependents. Given a level of income, the higher the number of dependents, the higher the burden on such a family, the greater will be the effect of subsidy removal on them. This finding supports a study [22] which observed that the high dependency ratios within households mean that labour is in high demand. All things been equal, high number of dependents indicates households strain on income and low number of dependents indicate less strain, reduced demand for fuel and other family needs. Marital status shows a positive coefficient $(0.698)$ and significant at $1 \%$ implying that the position of respondents with respect to marital status is an important factor influencing household livelihood in the study area. This may be due to the fact that married respondents usually have more responsibilities with higher fuel usage requirements compared to single respondents.

Secondary data collected from Npower office Maiduguri is presented in Table 5 which shows the various strategies adopted by government in alleviating negative effects accompanied by fuel subsidy removal in the study areas. Conditional cash transfer scheme (CCTS), a subsidiary of Subsidy of Social intervention Programme (SIP) introduced by the federal government have enrolled about 7,832 beneficiaries with each of them receiving 10,000 as monthly stipends. CCT provide opportunities for people in trading and farming opportunity to expand their businesses and farming activities, to be more efficient and to improve and acquire new skills in their various endeavors.

Table 5. Strategies launched against fuel subsidy effects.

\begin{tabular}{|c|c|c|}
\hline Strategy & Beneficiaries & Amount per individual \\
\hline $\mathrm{CCT}$ & 7832 & $\$ 10,000$ \\
\hline $\mathrm{V} / \mathrm{Cs}$ & 208 & $\$ 10,000$ \\
\hline Npower & 3389 & $\$ 30,000$ \\
\hline GEEP & 2667 & $\$ 10,000$ \\
\hline STEM & 300 & $\approx 50,000$ \\
\hline
\end{tabular}

$\mathrm{CCT}=$ conditional cash transfer scheme. GEEP= Government Enterprises and $S T E M=$ Science, Technology, Engineering and Mathematics.

Source: Npower office Maiduguri, 2017.

Vocational centers across the study areas have captured 208 beneficiaries with monthly allowances of $\$ 10,000$. It is designed to provide vocational training to unskilled persons and to enable them acquire desired skills in order to be selfreliance and also to reduce the level of unemployment in the country. Areas covered by the scheme include welding, carpentry, mechanical works, weaving, beads making and 
brick making. Npower has 3,387 beneficiaries with monthly allowances of $\$ 30,000$. It is designed to provide unemployed graduates with the necessary skills in the areas of teaching, agro technology, and health care services, the initiative is part of government effort in ensuring that the incessant fall in the quality of education, which results in low quality output as well as the problem of inadequate teaching staff in schools is addressed in the country. Those under the agro technology were trained in the various agricultural extension services to assist the Federal Government derive in realizing its diversification agenda. Likewise, those under healthcare were to serve as assistants in hospitals and clinics to complement the efforts of permanent staffs with the view of providing efficient healthcare services in the nation building.

Government Enterprises and Empowerment Programme has 2,667 enrollees receiving 10,000 . The scheme is among the social intervention programmes of the present administration committed to improving the socioeconomic standard of the vulnerable in the society aimed at empowering market women, traders, artisans, and others with the disbursement of interest free loans to the beneficiaries. With respect to science, technology, mathematics and engineering, a total of 300 candidates were captured as beneficiaries of the scheme in the study area with each of them receiving a sum of $\$ 50,000$ on monthly basis.

\section{Conclusion}

The socioeconomic characteristics showed that about 70.4\% of respondents in the study area were male, about $61.3 \%$ were married, $41.5 \%$ fall within the ages of 30-39 years. Besides, $50.7 \%$ had tertiary education, $52.1 \%$ were civil servants and about $34.5 \%$ have income level ranges between $\$ 40,000$ $\$ 59,999$ monthly. It was also revealed that $56.3 \%$ of the respondents had $8-10$ family members, while $57.7 \%$ of them have $1-5$ dependents. These were the socioeconomic factors that influence household's livelihood in the study areas.

Regression analysis revealed that family size, sex, dependency ratio, and education level, except age, are positive and significantly impacted household's livelihood in the study area. Results of the descriptive analysis show that $76 \%$ of the respondents agreed that fuel subsidy removal have decreased their level of income, $71.1 \%$ agree that it has decrease their savings. However, $90.1 \%$ agreed that it has led to a decrease in assets holding. In addition, $87.4 \%$ agree it has reduced occupational prospect. With respect to decline in knowledge/skill, about $91.5 \%$ of the respondents agree, while $78.9 \%$ also agree that it has decreased the level of employment. Results on the strategies employed to cushion hardship accompanied by subsidy removal revealed that the introduction of conditional cash transfer scheme (CCT), introduction of vocational centres, introduction of N-power, government enterprises and empowerment programme, and science, technology, engineering and mathematics (STEM), were the strategies adopted by government in the study area and have revealed a high level of awareness by respondents. Also, descriptive results show that $76.6 \%$ of the respondents agree that the introduction of conditional cash transfer is a strategy for cushioning hardship against the effect of fuel subsidy removal, $79.6 \%$ agree with introduction of vocational centres, $91.5 \%$ agree that Npower is also a means of alleviating the effect of fuel subsidy removal. Besides, $83.1 \%$ agree that government enterprises and empowerment programme while $78.9 \%$ agree that science technology and engineering as a strategy for cushioning hardship accompanied by fuel subsidy removal.

The essence of governance is to provide adequate welfare to meet the needs of the teeming population. The removal of subsidy on fuel has affected respondents and impacted negatively, which ultimately reflected in their livelihoods. The study concluded that some socioeconomic characteristics of respondents captured in the questionnaire influenced their wellbeing. These include educational level, level of income, number of dependent and size of the family.

It was also established that there is a significant relationship between fuel subsidy removal and household's livelihood in the study area. Furthermore, the study depict that subsidy removal have effect on the livelihood of the respondents in the study area. Palliative measures put in place by the government to cushion the hardship accompanied by subsidy removal has been perceived by most of the respondents as a means of reducing hardship associated with fuel subsidy removal in the study area.

In the light of the above findings, this study recommends household income, which was identified as a shock absorber against the effect of fuel subsidy removal in the study area is very low among the respondents. It is important that improving wages through the minimum wage scheme and provision of conducive environment for businesses are crucial in reducing hardship accompanied by fuel subsidy removal on households. Large household sizes and high number of dependents were found to affect household welfare in the study area as a result of fuel subsidy removal. Therefore, policy measures directed towards the provision of better family planning, increased awareness and access to family planning facilities should be given adequate attention and priority by the government. In view of this, strategies for an effective community participation in the design of concepts and messages aimed at imparting knowledge about family planning to households are recommended.

Government should subsidize transportation service in order to reduce the hardship of increase in prices of goods and services brought about by increase in petroleum price. The study indicates that the level of education also influence households livelihood (especially civil servants), therefore, incentives should be made available in the form of scholarship in order to improve their knowledge/skills so as to sustain their means of livelihoods. The study also found that all the strategies adopted by government to cushion the effects of subsidy removal were perceived by the respondents as a step in the right direction. However, there is need for such schemes to be more inclusive especially in the rural areas across Borno State. In view of this, more allocation of the nation's budget with respect to these palliatives is 
necessary to achieve this objective.

\section{References}

[1] Adebiyi, O. (2011). Fuel Subsidy: The True Story: Csp. Africa 23 Next. Available Online At: Http://234Next.Com/Csp/Cms/Sites/Next/Home/5764 671822/ (Retrieved 19 March 2015).

[2] Abang, I. Compensation Mechanisms for Fuel Subsidy Removal in Nigeria. International Institute for Sustainable Development 2016.

[3] Adeyemi, O. (2011). Socioeconomic Characteristics Influencing Farm Household Participation in Gandu Local Government Area of Katsina State: Nigeria.

[4] Ajayi, O. (2008). Assessment of Utilalisation of Energy Resources in Nigeria Energy Policy; 37: 750-753.

[5] Akande, L. (2017). Social Intervention Programmes- Premium Times Nigeria: http://www.premiumtimesng.com. Retrieved 14 September, 2017.

[6] Amaza, P., Abdoulaye, T., Kwaghe, P. \& Tegbasu A. (2009). Changes in Household Food Security and Poverty Status in PROSAB Area of Southern Borno State: Nigeria. Pp 6.

[7] Arze, G. (2012). The unequal Benefits of Fuel Subsidies: $A$ Review of Evidence of Developing Countries. 40 (3): 31.

[8] Bashir, D. (2014). The Economic Implication of Fuel Subsidy Removal in Nigeria. https://kkgpublications.com. Retrieved 27 July, 2019.

[9] Centre for Public Policy Alternatives (2012). Fuel Subsidy: $A$ Lesson for Nigeria. Geneva: Centre for Public Policy Alternatives. Pp. 22.

[10] El- said, (2006). Regional Economic Outlook, Sub-Saharan Africa. www.article.sapab.org.com. Retrieved 22 November, 2016.

[11] Eidis, D. (2012) Livelihood Connect: www.eldis.org/index.cfm. Retrieved 5 September, 2017.

[12] Eyiuche, A. C. (2012). The Socio-Economic Implication of the Fuel Subsidy Removal. Ibadan: Abok Publishers.

[13] Hope, F. \& Sigh, B. (1995). Energy Price Increases in Developing Countries. Case Study of Gambia and Ghana. 3 (5): 32.

[14] Iba, L. (2009). "Fuel Crisis: Will deregulation roll away all our problems?", Daily Sun, International Energy Agency (IEA). October 5, (1999). 3 (39). World Energy Outlook 1999: Looking at Energy Subsidies -Getting the Prices Right. International Energy Agency: Paris.

[15] Ijaiyi, G. T. (2007). "Privatization and Commercialization of Public Enterprises in Nigeria” in Institute Working Paper, 3 (1): 19.

[16] Junk, V. W., Junk, W. S., \& Jones, J. C. (2002). "Impacts of Energy Audits on Home Energy Consumption," Journal of Consumer Studies and Home Economics, (11): 2 21-23.

[17] Keeley, S. (2001). The potential of Using Sustainable Livelihood Approaches in Poverty Reduction strategies. www.fao.org/decrap. Retrieved 22 February, 2018.
[18] Luis, C. (2012). Energy Supply for Sustainable Rural Livelihood, A Multi Criteria Decision-Support System. (44): 1. 79 .

[19] McGee, (2002). Participation in Poverty Reduction Strategies: A Synthesis of Experience with Participatory to Policy Design, Implementation and Monitory. Paper 109, Briton Institute of Development Studies.

[20] Mefimisebi, T. (2013). Fundamentals of Cattle Marketing in Southwest, Nigeria: Analysing Market Intermediaries, Price formation and Yield Performance. (1): 2.

[21] NBS: Public Statement on World Statistics Day 2015.

[22] Netting, D. \& Robert. (1993). Smallholders, Householders: farm families and the Ecology intensive (3): 7.

[23] News agency of Nigeria (NAN) (2012) "Only full deregulation of downstream sector will end fuel scarcity". http://www.vanguardngr.com/2012/11/.

[24] Norton, L. \& Foster, H. (2001). Tools for Sustainable Livelihood: Strategies for Change. www.fao.org/decrap. Retrieved 22 February, 2018.

[25] Nkagu, R. (2012). Fuel Subsidies in Nigeria: an economic Necessity and a Political Dilemma. http//www.bookings.edu. Retrieved 4 March, 2016.

[26] Ocheni, S. (2015). Impact of Fuel Price Increase on Nigerian Economy. Mediterranean journal of social sciences, Department of Accounting Kogi State University, Ayugba 6 (1).

[27] Ojo, O. (2013). Effects of women's socioeconomic characteristics on households fuel consumption in Domboa Local Government Borno state. 3 (1): 8.

[28] Olawale, S. (2013). Political Economy of Phasing Out Fuel Subsidy in Nigeria, energy and power 1: (10).

[29] Opayemi, A. (2015). Fuel Subsidy Reform and Environmental Quality in Nigeria. http://www.econjournals.com.index. Retrieved 15 July, 2015.

[30] Oyodele, T. (2009) The Real Cost of Fuel Subsidy and Tax Implication. http://www.edufocus.com

[31] Pasteur, C. (2001). A Sustainable Livelihoods Approaches at Different Levels. www.fao.org/decrap. Retrieved 22 February, 2018.

[32] Regalema, F. (2000). Coping or Struggling? A Journey in to The Impact of HIV/AIDs in South Africa. https://www.researchget.net/publications

[33] Remy, U. (2012). The Impact of Fuel Subsidy Removal on Socioeconomic Development. Journals of Economics, Commerce and Management. 1 (2).

[34] Osagie, E. (2012). Evaluation of the Impact of Oil Subsidy Removal in South East Nigeria. https://www.slideshare.net/mobile.com. Retrieved 12 March, 2018.

[35] Todaro. H. (2009). A General Equilibrium Analysis of Production Subsidy in Haris Todaro Developing Economy: An Application to India. Applied Economics, Taylor Francis journals, vol, 41 (21) https://ideas.respect.org.com. Retrieved 12 March, 2018. 